\title{
Question Box Dalam Pembelajaran IPS Dengan Model Creative Problem Solving Meningkatkan Hasil Belajar IPS Siswa
}

\author{
Ni Made Rosita Dewi ${ }^{1}$, I Wayan Widiana ${ }^{2}$ \\ 1,2 Prodi Pendidikan Guru Sekolah Dasar, Jurusan Pendidikan Dasar \\ Universitas Pendidikan Ganesha \\ e-mail: rosita.id2017@gmail.com,wayan_widiana@yahoo.com
}

\begin{abstract}
Abstrak
Belum optimalnya hasil belajar IPS siswa kelas IV SD Gugus XI Kecamatan Buleleng menjadi alas an utama dilakukannya penelitian ini. Penelitian ini bertujuan untuk menganalisis pengaruh model pembelajaran Creative Problem Solving (CPS) berbantuan media Question Box terhadap hasil belajar IPS. Jenis penelitian ini yaitu penelitian eksperimen dengan menggunakan rancangan non equivalent post-test only control group design. Populasi pada penelitian ini adalah seluruh siswa kelas IV SD di Gugus XI Kecamatan Buleleng yang berjumlah 118 orang. Dari populasi tersebut kemudian diambil sampel dengan teknik random sampling sehingga diperoleh sampel dalam penelitian ini berjumlah 70 siswa. Pengumpulan data dalam penelitian ini dilakukan dengan menggunakan instrumen tes objektif dalam bentuk pilihan ganda. Data yang diperoleh dianalisis menggunakan uji-t. Berdasarkan hasil analisis uji-t diperoleh thitung $=2,384$ sedangkan ttabel $=1,995$ pada taraf signifikan $5 \%$ untuk derajat kebebasan $36+34-2=$ 68. Berdasarkan kriteria penghitungan karena thitung $>$ ttabel maka terdapat perbedaan yang signifikan antara kelompok siswa yang dibelajarkan dengan model pembelajaran Creative Problem Solving dengan kelompok siswa yang dibelajarkan dengan model konvensional. Dari hasil analisis uji-t tersebut dapat disimpulkan bahwa model pembelajaran Creative Problem Solving berpengaruh positif terhadap hasil belajar IPS siswa. Implikasi penelitian ini yaitu model Creative Problem Solving berbantuan media Question Box sesuai untuk diterapkan, karena model ini dapat melatih siswa untuk berpikir kritis dalam menyelesaikan setiap permasalahan secara kreatif, sehingga tujuan pembelajaran dapat tercapai.
\end{abstract}

Kata kunci: Model CPS, Question Box, Hasil Belajar

\begin{abstract}
This study aims to analyze the effect of the Creative Problem Solving (CPS) learning model assisted by the Question Box media on social studies learning outcomes. This type of research is experimental research using a non-equivalent post-test only control group design. The population in this study were all grade IV elementary school students in Cluster XI Buleleng District, totaling 118 people. From this population samples were then taken by random sampling technique, so that the samples in this study were 70 students. Data collection in this study was carried out using objective test instruments in the form of multiple choice. The data obtained were analyzed using t-test.

Based on the results of the t-test analysis obtained tcount $=2.384$ while ttable $=1.995$ at a significant level of $5 \%$ for degrees of freedom $36+34-2=68$. Based on the calculation criteria because tcount> ttable then $\mathrm{HO}$ is rejected and $\mathrm{H} 1$ is accepted. The results of the analysis prove that there are significant differences between groups of students who are taught with the Creative Problem Solving learning model and groups of students who are taught with conventional models. From the results of the t-test analysis and the average student learning outcomes it can be concluded that the Creative Problem Solving learning model has a positive effect on students' social studies learning outcomes. The implication of this research is the Creative Problem Solving model assisted media question box is appropriate to apply, because ths model can train student to think creatively in solving each problem creatively so that learning objectives can be achieved.
\end{abstract}

Keywords: CPS Models, Question Box, Learning Outcomes 


\section{Pendahuluan}

IPS merupakan wahana pencapain tujuan pendidikan untuk mengembangkan kemampuan dan membentuk watak serta peradaban bangsa. Menurut Saidiharjo (dalam Murda dan Yudiana, 2016), mengungkapkan bahwa IPS adalah hasil kombinasi atau hasil pemfusian atau perpaduan dari sejumlah mata pelajaran seperti geografi, ekonomi, sejarah, antropologi, dan politik. IPS merupakan perkembangan ilmu pengetahuan yang berhubungan dengan bidang praktik pendidikan (Lasmawan, 2016). Sedangkan menurut Buchari (dalam Susanto, 2013) IPS sebagai suatu program pendidikan yang merupakan suatu keseluruhan yang pada pokoknya mempersoalkan manusia dalam lingkungan alam fisik, maupun dalam lingkungan sosialnya dan yang bahannya diambil dari berbagai ilmu sosial. IPS memiliki beberapa tujuan, tujuan IPS menurut Mustakin (dalam Susanto, 2013) tujuan pembelajaran IPS adalah memiliki kesadaran dan kepedulian terhadap masyarakat atau lingkungannya melalui pemahaman terhadap nilai-nilai sejarah dan kebudayaan masyarakat. Tujuan pembelajaran IPS tidak hanya menekankan pada aspek pengetahuan saja, melainkan juga pembinaan peserta didik untuk mengembangkan dan menerapkan nilai-nilai pengetahuan tersebut di masyarakat. Hal ini sejalan dengan pendapat Wijaya (2015) bahwa mata pelajaran IPS sangat penting dibelajarkan untuk mengembangkan pengetahuan, keterampilan, sikap, dan nilai-nilai peserta didik dan mempersiapkan peserta didik menjadi warga negara yang baik yang kelak dapat berguna bagi lingkungan, masyarakat, dan negaranya.

Pengembangan pengetahuan tentunya dapat dilihat dari hasil belajar. Menurut Susanto (2013:5) hasil belajar adalah pengetahuan yang diperoleh anak setelah mengikuti kegiatan belajar dari suatu interaksi antara pengajar dan pendidik. Selain itu Junaidi (2019) berpendapat hasil belajar adalah kemampuan menerima atau menolak suatu penilaian berdasarkan pengalaman yang diperoleh setelah dilakukan evaluasi berupa tes yang mencakup penilaian kognitif (pengetahuan atau ingatan), afektif (sikap menerima), dan psikomotorik (keterampilan). Untuk menghasilkan hasil belajar yang optimal perlu adanya komponen penunjang dalam pembelajaran yaitu sarana prasarana, strategi, model, metode, dan media pembelajaran yang sesuai dengan materi pembelajaran. Dengan adanya fasilitafasilitas tersebut tentu akan mempermudah siswa dalam mengikuti kegiatan pembelajaran secara menyeluruh. Namun pada kenyataannya di lapangan guru masih sering menggunakan model pembelajaran yang kurang bervariasi dan tidak didukung dengan media pembelajaran khususnya pada mata pelajaran IPS. Pembelajaran IPS yang seharusnya dapat mengaktifkan siswa dalam proses pembelajaran, dalam pelaksanaannya justru dikeluhkan oleh siswa karena sebagaian besar materinya bersifat hafalan semata yang tentu akan mengurangi semangat siswa dalam belajar. Dalam penyamapaian materi pembelajaran guru kurang menggunakan model pembelajaran yang tepat karena kebanyakan dari guru masih menggunakan metode ceramah. Lestari (2019) berpendapat bahwa penggunaan model pembelajaran yang kurang tepat, bahkan hanya menggunakan ceramah akan membuat peserta didik kurang berantusias dalam mengikuti pembelajaran. Penggunaan model pembelajaran yang kurang tepat akan menumbuhkan rasa bosan pada diri siswa saat belajar, sehingga siswa tidak memiliki gairah dan tidak tertarik untuk mengikuti pembelajaran yang diajarkan oleh guru dengan menggunakan metode yang monoton. Sejalan dengan pendapat Sulfemi dan Nunung (2019) yang menyatakan bahwa, masalah yang paling mendasar yang dikeluhkan oleh peserta didik dalam pembelajaran IPS adalah peserta didik merasa bosan dan jenuh dengan proses kelas yang dalam pembelajarannya cenderung bersifat monoton. Hal ini disebabkan karena kurangnya keterlibatan siswa saat proses pembelajaran sehingga membuat siswa kurang aktif dan cenderung pasif dalam pembelajaran di kelas. Sejalan dengan pendapat Lasmawan (2016) bahwa pada jenjang pendidikan Sekolah Dasar menunjukkan indikasi bahwa pola pembelajaran yang dikembangkan oleh guru cenderung bersifat guru sentris, siswa hanya menjadi objek pembelajaran, sehingga prestasi belajar yang dicapai siswa kurang optimal. Hal ini tentu saja akan sangat berpengaruh pada hasil belajar IPS yang akan dicapai siswa. Dari pemaparan diatas hal ini juga terjadi di Sekolah Dasar Gugus XI Kecamatan Buleleng.

\footnotetext{
Received 19 April 2020, Accepted 19 Juni 2020; Available online 5 Juli 2020
} 
Berdasarkan hasil observasi yang dilakukan pada 28 Oktober dan 31 Oktober 2019 dengan wali kelas IV di Sekolah Dasar Gugus XI Kecamatan Buleleng diperoleh beberapa permasalahan yang terjadi yaitu 1) redahnya hasil belajar IPS, 2) kurangnya penggunaan model yang bervariasi dan inovatif, 3) kurangnya ketertarikan siswa untuk belajar dikarenakan guru belum menggunakan media pembelajaran secara optimal sehingga siswa sulit untuk menangkap dan memahami materi pembelajaran. Hal ini juga didukung berdasarkan hasil wawancara yang dilakukan bahwa terdapat permasalahan yang ada seperti 1) siswa merasa bosan karena menganggap materi IPS bersifat hafalan, 2) pembelajaran yang dikembangkan masih bersifat guru sentris dan, 3) masih ada beberapa siswa yang bercanda saat proses pembelajaran berlangsung sehingga mengganggu konsentrasi siswa yang lainnya.

Dampak yang akan ditimbulkan jika permasalahan tersebut tidak mendapatkan solusi adalah pada hasil belajar yang kurang optimal. Dilihat dari hasil studi dokumen yang diperoleh data ulangan tengah semester pada mata pelajaran IPS disajikan pada tabel 1 berikut.

Tabel 1 Nilai Ulangan Tengah Semester Siswa Kelas IV SD di Gugus XI Kecamatan Buleleng Tahun Pelajaran 2019/2020.

\begin{tabular}{|c|c|c|c|c|c|c|c|c|}
\hline \multirow[b]{2}{*}{ No } & \multirow[b]{2}{*}{ Sekolah } & \multirow[b]{2}{*}{ Kelas } & \multirow{2}{*}{$\begin{array}{l}\text { Jumlah } \\
\text { Siswa }\end{array}$} & \multirow[b]{2}{*}{$\mathrm{KKM}$} & \multirow[b]{2}{*}{ Rata-rata } & \multicolumn{3}{|c|}{ Nilai } \\
\hline & & & & & & 70-79 & $80-89$ & $90-100$ \\
\hline 1 & $\begin{array}{l}\text { SD Lab } \\
\text { Undiksha }\end{array}$ & IVA & 36 Siswa & 70 & 82,36 & 8 Siswa & $\begin{array}{l}16 \\
\text { Siswa }\end{array}$ & $\begin{array}{l}12 \\
\text { Siswa }\end{array}$ \\
\hline 2 & $\begin{array}{l}\text { SD Lab } \\
\text { Undiksha }\end{array}$ & IVB & 34 Siswa & 70 & 76,32 & $\begin{array}{l}24 \\
\text { Siswa }\end{array}$ & $\begin{array}{l}2 \\
\text { Siswa }\end{array}$ & $\begin{array}{l}8 \\
\text { Siswa }\end{array}$ \\
\hline 3 & $\begin{array}{l}\text { SDN } \\
\text { Kampung } \\
\text { Bugis }\end{array}$ & IV & 19 Siswa & 70 & 76,00 & $\begin{array}{l}13 \\
\text { Siswa }\end{array}$ & $\begin{array}{l}5 \\
\text { Siswa }\end{array}$ & $\begin{array}{l}1 \\
\text { Siswa }\end{array}$ \\
\hline 4 & $\begin{array}{l}\text { SDN } 1 \\
\text { Kampung } \\
\text { Anyar }\end{array}$ & IV & 12 Siswa & 70 & 76,47 & 8 Siswa & $\begin{array}{l}3 \\
\text { Siswa }\end{array}$ & $\begin{array}{l}1 \\
\text { Siswa }\end{array}$ \\
\hline 5 & $\begin{array}{l}\text { SDN } \\
\text { Kampung } \\
\text { Anyar }\end{array}$ & IV & 17 Siswa & 70 & 77,46 & $\begin{array}{l}10 \\
\text { Siswa }\end{array}$ & $\begin{array}{l}6 \\
\text { Siswa }\end{array}$ & $\begin{array}{l}1 \\
\text { Siswa }\end{array}$ \\
\hline & Jumlah & & 118 Siswa & & & $\begin{array}{l}55 \\
\text { Siswa }\end{array}$ & $\begin{array}{l}32 \\
\text { Siswa }\end{array}$ & $\begin{array}{l}23 \\
\text { Siswa }\end{array}$ \\
\hline
\end{tabular}

(Sumber: Wali Kelas IV SD di Gugus XI Kecamatan Buleleng)

Sesuai dengan panduan penilaian untuk SD dapat dapat diketahui rentangan predikat untuk nilai kurang dari tujuh puluh (70) dikategorikan "perlu bimbingan", nilai antara tujuh puluh (70) sampai tujuh puluh sembilan (79) dikategorikan "cukup", nilai antara delapan puluh (80) sampai sembilan puluh (90) dikategorikan "baik", dan nilai antara sembilan puluh (90) sampai seratus (100) dikategorikan "sangat baik". Dapat dilihat dari 118 siswa, 55 siswa mendapat nilai "cukup" 32 siswa mendapat nilai "baik", dan 23 siswa mendapat nilai "sangat baik". Dilihat dari tabel 1 diatas, maka hal tersebut menunjukkan bahwa hasil belajar IPS siswa belum optimal. Salah satu upaya yang dapat dilakukan guru adalah mengaitkan pembelajaran dengan kehidupan sehari-hari siswa. Dalam pembelajaran guru harus menciptakan suasana pembelajaran yang menyenangkan dan memberikan kesempatan kepada siswa untuk menggali kemampuannya sendiri, sehingga siswa aktif dalam mengikuti pembelajaran. Oleh sebab itu, dalam setiap materi pembelajaran diperlukan model pembelajaran yang dapat membangkitkan motivasi siswa dalam belajar. Salah satu model pembelajaran yang dapat diterapkan adalah model pembelajaran Creative Problem Solving. Menurut Pepkin (dalam Putra, 2018) model pembelajaran Creative Problem Solving adalah model pembelajaran yang memusatkan pada pengajaran dan keterampilan masalah, yang diikuti dengan penguatan 
keterampilan. Sedangkan Nopitasari (dalam Isrok'atun dan Rosmala, 2018:148) mengemukakan bahwa model pembelajaran Creative Problem Solving adalah salah satu model pembelajaran pemecahan masalah yang menekankan penemuan berbagai alternatif ide atau gagasan, untuk mencari penyelesaian berupa solusi yang paling efisien dari suatu permasalahan menggunakan proses berpikir divergen dan konvergen. Model pembelajaran Creative Problem Solving menjadikan siswa lebih aktif karena siswa dituntut dan diberikan kesempatan berpikir kritis agar mampu menemukan solusi dari permasalahan secara kreatif. Kelebihan dari model Creative Problem Solving menurut Saefullah (dalam Isrok'atun dan Rosmala 2019:151) yaitu (1) siswa dapat berpartisipasi aktif selama proses pembelajaran, (2) dapat menanamkan rasa ingin tahu siswa, (3) melatih kemampuan berpikir siswa dalam memecahkan masalah, dan (4) menumbuhkan kerjasama dan interaksi antarsiswa. Pada pelaksanaan model pembelajaran Creative Problem Solving tentunya terdapat langkahlangkah dalam penerapannya yang meliputi (1) Objective Finding, pada tahap ini siswa mendiskusikan permasalahan yang diberikan oleh guru (2) Fact Finding, pada tahap ini siswa menemukan informasi yang tidak diketahui (3) Problem Finding, pada tahap ini siswa mengidentifikasi kemungkinan pernyataan masalah (4) Idea Finding, pada tahap ini siswa mengungkapkan berbagai macam ide atau gagasan yang ditemukan (5) Solution Finding, pada tahap ini siswa dan guru melakukan proses evaluasi untuk menemukan solusi yang tepat dan (6) Acceptance Finding, pada tahap ini siswa sudah mulai menerima solusi dan mengimplementasikan solusi tersebut.

Dilihat dari pengertian dan kelebihan model pembelajaran Creative Problem Solving, maka model pembelajaran Creative Problem Solving cocok digunakan dalam proses pembelajaran terutama pada mata pelajaran IPS. Hal ini dikarenakan, selama ini siswa hanya mendengarkan penjelasan dari guru saja tanpa memberikan kesempatan kepada siswa untuk , namun dengan adanya model pembelajaran Creative Problem Solving ini siswa diberikan kesempatan untuk melatih kemampuan berpikir kritisnya, sehingga seluruh siswa terlibat aktif dalam proses pembelajaran. Hasil penelitian yang dilakukan oleh Yuliani (2018) menyatakan bahwa penggunaan model pembelajaran creative problem solving berbantuan media bongkar pasang berpengaruh positif terhadap kemampuan berpikir kreatif siswa.

Model pembelajaran Creative Problem Solving ini akan lebih efektif digunakan jika dibantu dengan media pembelajaran. Media pembelajaran juga sangat mempengaruhi proses pembelajaran agar siswa lebih mudah memahami materi sehingga mampu mengaktifkan siswa. Hal ini sesuai dengan pendapat Soleha (2019) yaitu pemilihan media pembelajaran yang tepat dapat menentukan kualitas dalam pembelajaran karena dengan adanya media pembelajaran akan membuat proses belajar mengajar menjadi menyenangkan dan siswa lebih antusias dalam belajar. Adanya media pembelajaran dapat membantu siswa berpikir secara nyata melalui media yang dipergunakan dalam poses pembelajaran karena dapat dilihat secara langsung. Menurut Karina dan Puspasari (2017) media pembelajaran merupakan teknologi pembawa pesan dan sarana komunikasi dalam bentuk cetak maupun pandang yang digunakan dalam penyampaian informasi dari pendidik kepada peserta didik. Sedangkan menurut Sadiman, dkk (dalam Tegeh, 2015) menyatakan bahwa kata "media" berasal dari bahasa latin dan merupakan bentuk jamak dari kata "medium" yang secara harfiah berarti "perantara atau pengantar". Jadi dapat disimpulkan media pembelajaran merupakan teknologi pembawa pesan informasi dari pengirim kepada penerima. Menurut Daryanto (dalam Aghni, 2018) media pembelajaran memiliki beberapa fungsi yaitu (1) memperjelas pesan agar tidak terlalu verbelistis, (2) mengatasi keterbatasan ruang, waktu, tenaga, dan daya indera, (3) menimbulkan gairah belajar, interaksi lebih langsung antara siswa fengan sumber belajar, (4) memungkinkan siswa belajar mandiri sesuai dengan bakat dan kemampuan visual, auditori, dan kinestetiknya, (5) memberi rangsangan yang sama, mempersamakan pengalaman dan menimbulkan persepsi yang sama, dan (6) proses pembelajaran mengandung lima komponen yaitu guru (komunikator), bahan pembelajaran, media pembelajaran, siswa (komunikan), dan tujuan pembelajaran. Salah satu media pembelajaran yang cocok dipadukan dengan model pembelajaran Creative Problem Solving adalah media Question Box. 
Menurut Menurut Pertiwi, dkk (2019) media Box Question merupakan media mengajar dengan melemparkan koin ke dalam box dimana setiap box terisi beberapa pilihan warna, kemudian setiap siswa yang melempar koin dan mendarat di warna yang tersedia akan diberikan pertanyaan yang ada pada kartu soal sesuai warna tersebut. Sedangkan menurut Salmea (2017) media Question Box adalah media sederhana yang dibuat berbentuk kotak yang di dalamnya berisi sejumlah pertanyaan yang akan diambil secara acak. Berdasatkan pendapat tersebut dapat disintesiskan bahwa Question Box adalah media alternatif bagi guru yang dibuat berbentuk kotak, setiap box terisi beberapa pilihan warna, kemudian setiap siswa yang melempar koin dan mendarat di warna yang tersedia akan diberikan pertanyaan yang ada pada kartu soal sesuai warna tersebut serta digunakan oleh guru untuk merangsang keterlibatan emosi dan intlektual siswa secara proporsional. Hasil penelitian (Pertiwi, dkk 2017) menyatakan dengan menggunakan media Question Box ini siswa mampu menjawab pertanyaan dari guru.

Berdasarkan pemaparan diatas diharapkan dengan menggunakan model pembelajaran Creative Problem Solving berbantuan media Question Box dapat mengaktifkan siswa dan merangsang kemampuan berpikir kritis siswa sehingga siswa mampu menyelesaikan permasalahan yang diberikan, dengan demikian maka hasil belajar siswa akan meningkat. Perbedaan penelitian ini dengan penelitian sejenis lainnya adalah penggunaan model pembelajaran Creative Problem Solving berbantuan media Question Box untuk meningkatkan hasil belajar IPS siswa. Adapun tujuan dari penelitian ini adalah untuk mengetahui apakah terdapat perbedaan hasil belajar antara siswa yang dibelajarkan dengan model pembelajaran Creative Problem Solving berbantuan media Question Box dengan kelompok siswa yang tidak dibelajarkan dengan model pembelajaran konvensional pada siswa kelas IV SD Gugus XI Kecamatan Buleleng Tahun Pelajaran 2019/2020.

\section{Metode}

Penelitian ini dilaksanakan di SD gugus XI Kecamatan Buleleng pada tahun pelajaran 2019/2020, dan berlangsung selama 6 kali pertemuan. Penelitian ini termasuk jenis penelitian semu (quasy eksperiment) karena tidak memungkinkan semua variabel dapat diatur dan dikontrol secara ketat. Penelitian ini menggunakan rancangan non equivalent post-test only control group design. Variable dalam penelitian ini dapat dikelompokkan menjadi variabel bebas dan variabel terikat. Variable bebas dalam penelitian ini adalah model pembelajaran Creative Problem Solving berbantuan media Question Box, sedangkan variable terikat pada penelitian ini adalah hasil belajar IPS.

Populasi pada penelitian ini adalah seluruh kelas IV SD di Gugus XI Kecamatan Buleleng Tahun Pelajaran 2019/2020. Banyak siswa seluruhnya adalah 118 orang yang terbagi menjadi 5 kelas yaitu kelas IVA SD Lab Singaraja (36), kelas IVB SD Lab Singaraja (34), kelas IV SDN 1 Kampung Bugis (19), kelas IV SDN 1 Kampung Anyar (12), dan kelas IV SDN 3 Kampung Anyar (17). Sampel dalam penelitian ini diambil menggunakan teknik random sampling dengan cara undian. Sebelum menentukan sampel dilakukan uji kesetaraan dengan menggunakan analisis varians satu jalur (Anava A). Kriteria pengujiannya adalah jika $F_{\text {hitung }}>F_{\text {tabel, }}$ maka $H_{0}$ ditolak dan $\mathrm{H}_{1}$ diterima, sehingga kelompok tersebut diinterpretasikan tidak setara. Jika $\mathrm{F}_{\text {hitung }}$ $<\mathrm{F}_{\text {tabel, }}$ maka $\mathrm{H}_{0}$ diterima dan $\mathrm{H}_{1}$ ditolak, sehingga kelompok tersebut diinterpretasikan setara. Berdasarkan hasil uji kesetaraan diperoleh $F_{\text {hitung }}<F_{\text {tabel }}$ sehingga kelompok tersebut diinterpretasikan setara. Setelah melakukan uji kesetaraan dilanjutkan dengan penentuan sampel menggunakan teknik random sampling dengan cara undian. Berdasarkan hasil undian diperoleh dua kelas yang dijadikan sampel penelitian yaitu kelas IVA SD Lab Singaraja yang berjumlah 36 orang siswa sebagai kelompok eksperimen yang diberikan perlakuan dengan model pembelajaran creative problem solving berbantuan media question box dan kelas IVB SD Lab Undiksha yang berjumlah 34 orang siswa sebagai kelompok kontrol yang dibelajarkan dengan model pembelajaran konvensional.

Prosedur dalam penelitian ini terdiri dari beberapa tahapan meliputi, tahap persiapan yang dilakukan oleh peneliti yaitu : (1) membawa surat pengantar untuk melaksanakan observasi ke sekolah tempat melaksanakan penelitian, (2) melaksanakan observasi awal ke 
sekolah tempat melaksanakan penelitian dan wawancara dengan wali kelas IV SD Gugus XI Kecamatan Buleleng, (3) menentukan sampel penelitian yang akan digunakan sebagai kelas eksperimen dan kelas kontrol dengan cara undian, (4) menyusun RPP, membuat media Question Box dan mempersiapkan pembelajaran dengan model Creative Problem Solving berbantuan media Question Box yang akan digunakan untuk pembelajaran di kelas eksperimen, (5) mengkonsultasikan instrument penelitian post-test dengan wali kelas dan dosen pembimbing, (6) mengkonsultasikan RPP dan media pembelajaran dengan dosen pembimbing, (7) Melaksanakan uji pakar (judgest), (8) merevisi instrument yang telah diujikan dan menyempurnakan instrument yang telah diujikan, (9) mengadakan uji coba instrument penelitian soal post-test. Tahap pelaksanaan eksperimen, tahap ini dilaksanakan oleh peneliti dengan memberikan perlakuan model pembelajaran Creative Problem Solving berbantuan media Question Box pada kelompok eksperimen. Sedangkan pada kelompok kontrol tidak diberikan perlakuan, perlakuan kepada kedua kelompok diberikan sebanyak 6 kali pertemuan. Selanjutnya, memberikan tes akhir (post-test) kepada kedua kelompok. Tahap akhir eksperimen melaksanakan analisis data untuk membuktikan hipotesis yang telah dirumuskan mengenai pengaruh model pembelajaran Creative Problem Solving berbantuan media Question Box terhadap hasil belajar IPS.

Data yang dikumpulkan dalam penelitian ini adalah data hasil belajar IPS siswa. Metode pengumpulan data hasil belajar mengggunakan metode tes dalam bentuk tes pilihan ganda dengan jumlah soal 30 butir. Pelaksanaan tersebut dilakukan dengan cara membagikan sejumlah tes untuk mengukur hasil belajar IPS siswa kelas IV. Penelitian ini dilakukan hanya untuk mengukur kemampuan siswa pada ranah kognitif atau pengetahuannya saja. Setiap soal dalam pilihan ganda tersebut dilengkapi dengan empat pilihan jawaban yaitu a, b, c, dan d. Setiap butir soal yang dijawab benar oleh siswa dengan mencocokkan jawaban dengan kunci jawaban diberi skor 1, sedangkan setiap butir soal yang dijawab salah oleh siswa diberi skor 0 . Masing-masing soal yang benar dijumlahkan dan jumlah skor tersebut dijadikan skor variable hasil belajar IPS siswa.

Data yang diperoleh kemudian dianalisis dengan menggunakan statistik deskriptif dan statistik inferensial. Statistik deskriptif dilakukan untuk mengetahui tinggi rendahnya kualitas dari hasil belajar siswa, baik yang dibelajarkan dengan menggunakan model creative problem solving maupun yang tidak dibelajarkan dengan model creative problem solving. Adapun analisis statistik deskriptif yang digunakan adalah mean, standar deviasi, dan varians. Untuk menentukan tinggi rendahnya kualitas hasil belajar IPS siswa, skor rata-rata tiap variabel dikonversikan dengan menggunakan kriteria rata-rata ideal $\left(\mathrm{M}_{\mathrm{i}}\right)$ dan standar deviasi ideal $\left(S D_{i}\right)$. Sebelum melakukan uji hipotesis menggunakan varians satu jalur (ANAVA A), terlebih dahulu dilakukan uji prasayarat. Uji asumsi yang harus dipenuhi adalah uji normalitas dan uji homogenitas varians. Setelah uji asumsi dipenuhi, maka dilanjutkan dengan pengujian hipotesis menggunakan analisis varians satu jalur (Anava A). Apabila uji anava satu jalur menunjukkan $\mathrm{H}_{1}$ artinya terdapat perbedaan hasil belajar IPS antara siswa yang dibelajarkan dengan model pembelajaran creative problem solving berbantuan media question box dengan siswa yang dibelajarkan model pembelajaran konvensional.

\section{Hasil dan Pembahasan}

Hasil penelitian ini menunjukkan bahwa terdapat pengaruh yang signifikan siswa yang yang dibelajarkan dengan model pembelajaran Creative Problem Solving berbantuan media Question Box terhadap hasil belajar IPS siswa kelas IV SD Gugus XI Kecamatan Buleleng. Hasil analisis statistik deskriptif data penelitian ini disajikan pada tabel 2 berikut. 
Table 2 Deskripsi Data Hasil Belajar Kelompok Eksperimen dan Kelompok Kontrol

\begin{tabular}{ccc}
\hline Statistik Deskriptif & Kelompok Eksperimen & Kelompok Kontrol \\
\hline N & 36 & 34 \\
Skor Maksimal & 30 & 27 \\
Skor Minimal & 15 & 13 \\
Mean & 22,67 & 20,09 \\
Standar Deviasi & 4,65 & 4,40 \\
Varians & 21,66 & 19,36 \\
\hline
\end{tabular}

Data hasil post-test kelompok eksperimen yaitu kelompok siswa yang mengikuti model pembelajaran Creative Problem Solving berbantuan media Question Box dan hasil post-test kelompok kontrol yaitu kelompok siswa yang dibelajarkan dengan model konvensional. Hasil post-test dari 36 siswa pada kelompok eksperimen menunjukkan skor tertinggi siswa adalah 30 dan skor terendah adalah 15, dengan mean 22,67, dan standar deviasi 4,65. Berdasarkan skala penilaian skor hasil belajar siswa kelompok eksperimen berada pada pada rentang skor $22,5 \leq 30$ dengan kategori sangat tinggi. Sedangkan hasil post-test dari 34 siswa pada kelompok kontrol menunjukkan skor tertinggi siswa adalah 27 dan skor terendah adalah 13, dengan mean 20,09, dan standar deviasi 4,40. Berdasarkan skala penilaian skor hasil belajar siswa kelompok kontrol berada pada pada rentang skor 17,5 $\leq \mathrm{M}<22,5$ dengan kategori tinggi. Dari hasil post-tes kedua kelompok tersebut terlihat adanya perbedaan hasil belajar IPS siswa.

Sebelum melakukan uji hipotesis, dilakukan uji normalitas sebaran data dan homogenitas kelompok varians. Berdasarkan analisis data yang dilakukan, data berdistribusi normal dan homogen sehingga bisa dilanjutkan pada pengujian hipotesis. Uji normalitas data dilakukan pada keseluruhan unit analisis yaitu kelompok eksperimen dan kelompok kontrol. Analisis yang digunakan pada pengujian normalitas sebaran data Chi-Kuadrat $\left(\mathrm{x}^{2}\right)$ dengan kriteria pengujian data berdistribusi normal jika $x^{2}$ hitung $<x^{2}$ tabel pada taraf signitifikan $5 \%$ derajat kebebasan $\mathrm{dk}=$ (jumlah kelas interval - parameter -1 ). Hasil uji normalitas sebaran data yang diuji menggunakan rumus chi kuadrat dan hpmpgenitas disajikan pada tabel 3 berikut.

Tabel 3 Uji Normalitas Sebaran data dan Homogenitas Kelompok Varians

\begin{tabular}{|c|c|c|c|c|c|c|c|c|}
\hline & \multicolumn{4}{|c|}{ Uji Normalitas } & \multicolumn{4}{|c|}{ Uji Homogenitas } \\
\hline No & $\begin{array}{c}\text { Kelompok } \\
\text { Data }\end{array}$ & $X^{2}$ & $\begin{array}{c}\text { Taraf } \\
\text { Signifikan } \\
5 \%\end{array}$ & Status & $\begin{array}{c}\text { Post-test } \\
\text { Kelompok } \\
\text { Eksperimen }\end{array}$ & $F_{\text {hitung }}$ & $\mathrm{F}_{\text {tabel }}$ & Status \\
\hline 1 & $\begin{array}{l}\text { Post-tes } \\
\text { Kelompok } \\
\text { Eksperimen }\end{array}$ & 6,46 & 7,814 & Normal & dan Kontrol & 1,12 & 1,78 & Homogen \\
\hline 2 & $\begin{array}{l}\text { Post-tes } \\
\text { Kelompok } \\
\text { Eksperimen }\end{array}$ & 4,16 & 7,814 & Normal & & & & \\
\hline
\end{tabular}

Berdasarkan hasil penghitungan menggunakan rumus chi-kuadrat, diperoleh $\chi_{\text {hit }}^{2}$ hasil post-test kelompok eksperimen adalah 6,46 dan $\chi_{\text {tab }}^{2}$ pada taraf signifikansi $5 \%$ dan $\mathrm{dk}=3$ adalah 7,814. Hal ini berarti, $\chi^{2}$ hit hasil belajar IPS kelompok eksperimen lebih kecil dari $\chi_{\text {tab }}^{2}$ $\left(\chi^{2}{ }_{h i t}<\chi^{2}{ }_{t a b}\right)$, sehingga data skor hasil belajar IPS kelompok eksperimen berdistribusi normal. Pada kelompok kontrol, $\chi^{2}{ }_{\text {hit }}$ hasil belajar IPS kelompok kontrol adalah 4,16 dan $\chi^{2}{ }_{\text {tab }}$ dengan taraf signifikansi $5 \%$ dan $\mathrm{dk}=3$ adalah 7,814 . Hal ini berarti, $\chi^{2}$ hit hasil belajar 
IPS kelompok kontrol lebih kecil dari $\chi_{\text {tab }}^{2}\left(\chi_{h i t}^{2}<\chi_{\text {tab }}^{2}\right.$, sehingga data hasil belajar IPS kelompok kontrol berdistribusi normal.

Uji homogenitas varians dilakukan berdasarkan data hasil belajar IPS pada kelas eksperimen dan kelas kontrol. Jumlah masing-masing unit analisis adalah 36 dan 34 orang siswa. Hasil uji homogenitas varians data hasil belajar IPS kelompok eksperimen dan kelompok kontrol diperoleh $F_{\text {hitung }}=1,12$. Nilai tersebut kemudian dikonsultasikan dengan harga $F_{\text {tabel }}$ dengan taraf signifikansi $5 \%$ dengan pembilang $=35$ dan penyebut $=33$. Jadi hasil analisis $F_{\text {tabel }}=1,78$, karena $F_{\text {hitung }} 1,12<1,78$ maka dapat dikatakan data hasil belajar IPS kelompok eksperimen dan kelompok kontrol mempunyai varians yang homogen.

Berdasarkan data hasil belajar IPS yaitu berdistribusi normal dan varians data homogen dilanjutkan dengan pengujian hipotesis. Pengujian hipotesis dilakukan menggunakan uji-t dengan rumus separated varians sebagai berikut.

Kriteria pengujian yaitu $\mathrm{H}_{0}$ jika thitung $>$ table ditolak dan diterima jika $\mathrm{H}_{0}$ jika $t_{\text {hit }}<\mathrm{t}_{\text {tabel. }}$. Rekapitulasi hasil analisis uji-t ditunjukkan pada tabel 4 sebagai berikut.

Tabel 4 Rekapitulasi Hasil Uji-t

\begin{tabular}{ccccccc}
\hline Kelompok & $\mathrm{N}$ & $\mathrm{Db}$ & Mean & $\mathrm{S}^{2}$ & $\mathrm{t}_{\text {hitung }}$ & $\mathrm{t}_{\text {tabel }}$ \\
\hline Eksperimen & 33 & 68 & 22,67 & 21,66 & 2,384 & 1,995 \\
Kontrol & 32 & 68 & 20,09 & 19,36 & & \\
\hline
\end{tabular}

Berdasarkan rangkuman analisis uji $t$, dapat diketahui $t_{\text {hitung }}=2,384$ dan $t_{\text {tabel }}=1,995$ untuk $\mathrm{db}=68$ pada taraf signifikansi $5 \%$. Berdasarkan kriteria pengujian, karena $t_{\text {hitung }}>t_{\text {tabel }}$ maka $\mathrm{H}_{0}$ ditolak dan $\mathrm{H}_{1}$ diterima. Artinya, terdapat perbedaan yang signifikan hasil belajar IPS antara kelompok siswa yang dibelajarkan dengan model pembelajaran Creatve Problem Solving berbantuan media Question Box dengan kelompok siswa yang tidak dibelajarkan dengan model pembelajaran Creatve Problem Solving berbantuan media Question Box pada siswa kelas IV SD Gugus XI Kecamatan Buleleng Tahun Pelajaran 2019/2020. Hasil analisis data menunjukkan bahwa terdapat pengaruh yang signifikan model pembelajaran Creatve Problem Solving berbantuan media Question Box pada siswa kelas IV SD Gugus XI Kecamatan Buleleng tahun pelajaran 2019/2020.

Tinjauan ini didasarkan pada hasil uji-t dan rata-rata skor hasil belajar siswa. Analisis data menggunakan uji-t, diketahui thitung $=2,384$ dan $t_{\text {tabel }}$ pada taraf signifikansi $5 \%$. $=1,995$. Hasil penghitungan tersebut menunjukkan bahwa $t_{\text {hitung }}>t_{\text {tabel, }}$ sehingga hasil penelitian adalah signifikan. Selanjutnya berdasarkan rata-rata siswa yang mengikuti model pembelajaran Creatve Problem Solving berbantuan media Question Box 22,67 dan rata-rata hasil belajar siswa yang tidak dibelajarkan dengan model pembelajaran Creatve Problem Solving berbantuan media Question Box adalah 20,09. Hal ini menunjukkan bahwa hasil belajar kelompok siswa yang dibelajarkan dengan model pembelajaran Creatve Problem Solving berbantuan media Question Box lebih tinggi dibandingkan dengan hasil belajar kelompok siswa yang tidak dibelajarkan dengan model Creatve Problem Solving berbantuan media Question Box. Jadi, dapat disimpulkan bahwa hasil penelitian pembelajaran IPS di kelas IV yang dilakukan dengan menerapkan model pembelajaran Creatve Problem Solving berbantuan media Question Box yaitu hasil belajar siswa lebih meningkat. Hal ini dilihat dari rata-rata skor hasil belajar siswa yang mengikuti model pembelajaran Creatve Problem Solving berbantuan media Question Box adalah 22,67 dan rata-rata hasil belajar siswa yang tidak dibelajarkan dengan model pembelajaran Creatve Problem Solving berbantuan media Question Box adalah 20,09, sehingga dapat disimpulkan bahwa terdapat perbedaan hasil belajar IPS antara siswa yang dibelajarkan dengan model pembelajaran Creatve Problem Solving berbantuan media Question Box dengan siswa yang dibelajarkan dengan model pembelajaran konvensional pada siswa yang memiliki hasil belajar rendah. 
Uji hipotesis telah berhasil menolak $\mathrm{H}_{0} \mathrm{H}_{1}$, ini berarti terdapat perbedaan hasil belajar IPS antara siswa yang dibelajarkan dengan model pembelajaran Creatve Problem Solving berbantuan media Question Box dengan siswa yang dibelajarkan dengan model pembelajaran konvensional pada siswa kelas IV SD Gugus XI Kecamatan Buleleng Tahun pelajaran 2019/2020. Perbedaan hasil belajar antara kelompok eksperimen dan kontrol, dikarenakan model pembelajaran Creatve Problem Solving berbantuan media Question Box pada kelas eksperimen berlangsung lebih optimal dibandingkan dengan pembelajaran di kelas kontrol. Hal tersebut dapat dilihat dari: (1) penggunaan model pembelajaran Creatve Problem Solving dapat memberikan kesempatan kepada siswa untuk mencoba mencari tahu mengenai suatu fakta. Rasa ing in tahu siswa dapat meningkat dengan merangsang siswa menggunakan suatu peristiwa yang menantang, sehingga siswa berusaha untuk mencari tahu suatu masalah yang terkandung dalam peristiwa yang disajikan. Penerapan model pembelajaran Creative Problem Solving yang dibantu dengan media Question Box memudahkan dalam menyampaikan materi pembelajaran dan mampu mengaktifkan siswa untuk menemukan solusi yang paling efisien. Timbulnya solusi yang diyakini tepat dari permasalahan yang ada maka dapat meningkatkan rasa percaya diri siswa dalam mengemukakan pendapat mengenai permasalahan yang diberikan. Sejalan dengan pendapat yang dikemukakan oleh Saputra (dalam Muhamad 2017) yang menyatakan bahwa percaya diri adalah salah satu kesuksesan siswa dalam belajar. Timbulnya rasa percaya diri dalam diri siswa dapat membuat siswa berani dalam mengemukakan pendapat yang muncul dalam pemikirannya, (2) kesesuaian antara materi pembelajaran yang disampaikan dengan pengalaman belajar siswa. Guru memberikan kesempatan kepada siswa untuk berdiskusi dengan anggota kelompok. Pada saat menyelesakan masalah, terlihat aktivitas siswa dalam pembelajaran siswa mampu saling bertukar informasi untuk menyelesaikan setiap permasalahan yang diberikan oleh guru. Selain itu terjadi interaksi timbal balik antar kelompok satu dengan kelompok yang lain, yang tentunya akan memberikan perubahan positif pada diri siswa karena dalam proses pembelajaran siswa menjadi lebih aktif dan kreatif dalam menyelesaikan setiap permasalahan. Hal ini terlihat dari kegiatan siswa dalam mengikuti proses pembelajaran dan merespon pertanyaan yang diberikan oleh guru siswa menjadi termotivasi. Hal ini didukung dengan penelitian Anggraeni (2018) menyatakan bahwa, perencanaan pembelajaran yang disusun dengan menekankan pada beragam aktivitas yang menuntut siswa untuk lebih banyak terlibat aktif akan memberikan pengaruh pada pengalaman belajarnya, (3) dalam mencapai keberhasilan dalam tujuan pembelajaran, guru meberikan apresiasi berupa pujian, hadiah, senyuman, dan momotivasi siswa yang lain agar belajar lebih giat dan rajin sehingga dapat menguasai materi pembelajaran. Hal tersebut didukung dengan penelitian Hatta (2017) yang menyatakan bahwa kepuasan merupakan suatu sikap positif siswa terhadap pelayanan proses belajar mengajar yang dilaksanakan oleh guru karena adanya kesesuaian antara apa yang diharapkan dan dibutuhkan dengan kenyataan yang diterimanya. Adapun kelebihan model Creative Problem Solving menurut menurut Saefullah (dalam Isrok'atun dan Rosmala 2019) yaitu 1) siswa berpartisipasi aktif selama proses pembelajaran, 2) dapat menanamkan rasa ingin tahu siswa, 3) melatih kemampuan berpikir kreatif siswa dalam memecahkan masalah, dan 4) menumbuhkan kerjasama serta interaksi antarsiswa.

Berbeda halnya dengan kelas kontrol yang dibelajarkan dengan model pembelajaran konvensional. Pembelajaran konvensional menghadirkan suasana pembelajaran yang lebih berpusat pada guru yang tentunya akan berdampak pada rendahnya hasil belajar siswa karena pembelajaran yang dilakukan cenderung dirasa monoton. Hal ini sejalan dengan pendapat Nasution (2017) bahwa pembelajaran konvensional menjadikan guru sebagai sumber belajar bagi siswa, guru mengambil peran besar dalam proses transfer ilmu kepada siswa, guru menjelaskan pengetahuan yang dipelajari, sebaliknya siswa dengan tenang akan mendengarkan penjelasan dari guru. Pembelajaran seperti ini dapat dikatakan kurang melatih siswa dalam berpikir kreatif untuk menemukan ide atau gagasan.

Perbedaan hasil belajar IPS antara kelompok siswa yang dibelajarkan dengan model pembelajaran Creative Problem Solving berbantuan media Question Box dengan kelompok siswa yang dibelajarkan dengan model pembelajaran konvensional disebabkan karena perlakuan yang diberikan baik pada langkah-langkah pembelajaran maupun proses 
pembelajaran yang berbeda. Hasil belajar siswa yang tergolong sangat tinggi pada kelas eksperimen dengan menggunakan model pembelajaran Creative Problem Solving berbantuan media Question Box disebabkan karena model Creative Problem Solving berbantuan media Question Box lebih mengutamakan siswa untuk berpikir kreatif dalam proses pembelajaran sehingga mampu menemukan solusi yang paling efisien dari setiap permasalahan.

Pada pelaksanaan penelitian ini ditemukan bahwa penerapan model Creative Problem Solving berbantuan media Question Box dapat memberikan pembelajaran yang menyenangkan bagi siswa, sehingga dapat meningkatkan hasil belajar IPS. Pada penerapan model Creative Problem Solving berbantuan media Question Box, siswa dilatih untuk berpikir secara kreatif untuk memecahkan beberapa pertanyaan yang terdapat pada media Question Box. Dengan menggunakan media Question Box ini siswa merasa penasaran sehingga tertantang untuk mengikuti proses pembelajaran.

Hasil penelitian ini sesuai dengan penelitian yang dilakukan oleh Cahyani (2019) yang menyatakan bahwa ada pengaruh positif model pembelajaran Creative Problem Solving terhadap kemmapuan pemecahan masalah matematis kelas V SDN Pendeanlemper 01 Semarang. Dengan demikian, dapat disimpulkan bahwa penerapan model pembelajaran Creative Problem Solving berbantuan media Question Box berpengaruh positif dan signifikan terhadap hasil belajar IPS siswa.

\section{Simpulan}

Pembelajaran dengan model Creative Problem Solving berbantuan media Question Box menjadikan peserta didik lebih aktif dalam pembelajaran, khususnya dalam pembelajaran IPS. Hal ini terbukti berdasarkan hasil analisis data dari kelompok eksperimen yang berjumlah 36 orang siswa rata-rata hasil belajar yang diperoleh adalah 22,67 sedangkan pada kelompok kontrol yang berjumlah 34 orang siswa rata-rata hasil belajar yang diperoleh adalah 20.09. ini menandakan bahwa skor rata-rata hasil belajar siswa kelompok eksperimen lebih tinggi dibandingkan dengan kelompok kontrol. Selanjutnya, hasil analisis hipotesis dengan uji-t terhadap perolehan hasil belajar IPS pada sampel penelitian diperoleh $t_{\text {hitung }}=2,384$ dan $t_{\text {tabel }}$ pada taraf signifikan $5 \%$ sebesar 1,998 . Ini berarti nilai $t_{\text {hitung }}$ lebih besar dari $t_{\text {tabel }}(2,384>1,998)$ maka $\mathrm{H}_{0}$ ditolak dan $\mathrm{H}_{1}$ diterima. Sehingga dapat disimpulkan bahwa terdapat pengaruh yang signifikan model pembelajaran Creative Problem Solving berbantuan media Question Box terhadap hasil belajar IPS siswa kelas IV SD gugus XI Kevamatan Buleleng Tahun Pelajaran 2019/2020.

Adapun saran yang dapat disampaikan oleh peneliti yaitu sebagai berikut. (1) kepala sekolah dapat menerapkan model pembelajaran Creartive Problem Solving (CPS) berbantuan media Question Box sebagai salah satu alternative dalam pembelajaran di sekolah untuk meningkatkan hasil belajar siswa, (2) guru di sekolah dasar agar berinovasi dalam mengelola pembelajaran melalui penerapan model pembelajaran yang inovatif dan dalam pemanfaatan media pembelajaran yang relevan agar dapat meningkatkan hasil belajar siswa, dan (3) peneliti yang ingin mengadakan penelitian lebih lanjut tentang model pembelajaran Creartive Problem Solving (CPS) berbantuan media Question Box dalam meningkatkan hasil belajar IPS maupun pembelajaran yang lainya agar dapat memanfaatkan penelitian ini sebagai tambahan informasi dalam melakukan penelitian sejenis.

\section{Daftar Pustaka}

Aghni, R. I. (2018). Fungsi dan Jenis Media Pembelajaran dalam Pembelajaran Akuntansi. Jurnal Pendidikan Akuntansi Indonesia, 16(1), 98-107.

Anggraeni, P., \& Akbar, A. 2018. "Keseuaian Rencana Pelaksanaan Pembelajaran dan Proses Pembelajaran". Jurnal Pesona Dasar. vol. 6, No. 2.

Cahyani, S.D. 2019. "Pengaruh Mode Pembelajaran Creative Problem Solving (CPS) Terhadap Kemampuan Pemecahan Matematis Siswa". Mimbar PGSD Undiksha. Vol.7, No. 2.

Hatta, M. 2017. "Unsur-Unsur Dinamis Pembelajaran Fasilitas Belajar dan Motivasi 
Berprestasi Terhadap Kepuasan Siswa MTs". Jurnal Manajemen Pendidikan. Vol. 12, No. 1

Isrok'atun, \& Rosmala, A. (2018). Model-Model Pembelajaran Matematika. Jakarta: PT Bumi Aksara.

Junaidi. (2019). Pengaruh Model Pembelajaran Word Square Terhadap Hasil Belajar Fisika. SPEJ (Science and Physics Education Journal), 2(2).

Karina, D. S. (2017). Pengembangan Media Pembelajaran Question Card "Kompetensi Dasar Mengidentifikasi Alat dan Bahan Kearsipan Pada Siswa Kelas X APK 2 SMK" Adhikawacana Surabaya. Jurnal Administrasi Perkantoran (JPAP), 5(2).

Lasmawan, I. W. (2016). Pendidikan IPS. Singaraja: Mediakom Indonesia Press Bali.

Lestari, D. (2019). Penerapan Model Circuit Learning dalam Pembelajaran Menganalisis Unsur Puisi. Jurnal Pendidikan Dan Pembelajaran Bahasa Indonesia, 8(2).

Muhamad, N. 2017. "Pengaruh Metode Discovery Learning untuk Meningkatkan Representasi Matematis dan Percaya Diri Siswa". Jurnal Penelitian Universitas Garut. Vol. 9, No. 1.

Murda, N., \& Yudiana, K. E. (2016). Konsep Dasar IPS. Singaraja: Universitas Pendidikan Ganesha.

Nasution, P. R. 2017. "Perbedaan Peningkatan Kemampuan Berpikir Kreatif Matematis dan Kemandirian Belajar Siswa Pada Pembelajaran Berbasis Masalah da Pembelajaran Konvensional di SMPN 4 Padangsidimpuan". Vol. 2, No. 1.

Nopitasari, D. (2016). Pengaruh Model Pembelajaran Creative Problem Solving (CPS) Terhadap Kemampuan Penalaran Adaptif Matematis Siswa. Jurnal Matematika Dan Pendidikan Matematika, 1(2).

Pertiwi, P., Dony, N., \& Mashuri, M. T. (2019). Pengembangan Media Pembelajaran Box Question Pada Materi Sistem Koloid di MA Siti Mariam Banjarmasin. Dalton: Jurnal Pendidikan Kimia Dan IImu Kimia, 2(2).

Putra, Y. P. (2018). Penggunaan Model Pembelajaran Creative Problem Solving Untuk Meningkatkan Kemampuan Berpikir Kreatif dan Motivasi Belajar Matematika Siswa. Jurnal Pendidikan dan Pengajaran Matematika. Jurnal Pendidikan Dan Pengajaran Matematika, 4(2).

Salmia, N. (2017). Pengaruh Penerapan Model Pembelajaran Course Review Horay Berbantuan Media Question Box Terhadap Hasil Belajar Siswa Pada Materi Hidrokarbon. Universitas Islam Negeri Sultan Syarif Kasim Riau.

Soleha, S., Purnomo, A., \& Nisa, A. N. S. (2019). Pengaruh Media Pembelajaran Mind Map terhadap Hasil Belajar Siswa pada Mata Pelajaran IPS Kelas VII di SMP Negeri 38 Semarang. SOSIOLIUM: Jurnal Pembelajaran IPS, 1(1), 1-13.

Sulfemi, Bagja, W., \& Yuliani, N. (2019). Model Pembelajaran Contextual Teaching And Learning (CTL) berbantuan Media Miniatur Lingkungan Untuk Meningkatkan Hasil Belajar IPS. Jurnal IImiah Pendidikan Ekonomi Fakultas Keguruan Dan IImu Pendidikan, 7(2).

Susanto, A. (2013). Teori Belajar dan Pembelajaran di SD. Jakarta: Kencana Prenadamedia Group.

Tegeh, I. M. (2015). Media Pembelajaran. Singaraja: Universitas Pendidikan Ganesha.

Wijaya, Y. D. (2015). Pengembangan Bahan Ajar Mata Pelajaran IPS SMP Kelas VIII Pada Pokok Bahasan Permasalahan Lingkungan Hidup dan Upaya Penanggulangannya.

Yuliani, Irma, \& Dkk. (2018). Penerapan Model Pembelajaran Creative Problem Solving Berbantuan Media Bongkar Pasang Untuk Peningkatan Berpikir Kreatif Matematika. Jurnal IImiah Pendidikan Matematika. Jurnal IImiah Pendidikan Matematika, 1(1). 